\title{
Utilization OfThe Participatory Approach InThe Assessment Of Students' Academic Performance
}

\author{
Imelda J. Villarin ${ }^{1}$, Nemia F. Zamora ${ }^{2}$, Edwin A. Pilapil ${ }^{3}$, Simeon C. Bernados, \\ $\mathrm{Jr}^{4}$ \\ ${ }^{1}$ Chairman, Department of Languages, Literature, and Communication, College of Arts and Sciences, Cebu \\ Technological University, Cebu City, Philippines \\ ${ }^{2}$ Chairman, Community Extension Services Office, College of Arts and Sciences, Cebu Technological \\ University, Cebu City, Philippines \\ ${ }^{3}$ Dean, College of Arts and Sciences, Cebu Technological University, Cebu City, Philippines \\ ${ }^{4}$ Chairman,Research and Development Office, College of Arts and Sciences, Cebu Technological University, \\ Cebu City, Philippines
}

\begin{abstract}
Exploring the relation between the student-identified academic performance indicatorsand the academic performance of studentsis the main objective of this study. It was established that the instructional, family, and school organization support variables were indicators in their performance. It was argued in this paper that teachers, to improve the academic performance (AP) of students, have to focus on the improvement of the academic performance indicators (API) for the APIand AP are directly correlated.
\end{abstract}

Key words: academic performance, performance indicator, assessment, participatory

\section{INTRODUCTION}

Assessment of academic performance of students is an important task that governments and their instrumentalities have to undertake. Governments allocate a sizeable slice of their budget pie for the education of its citizens. True enough, educational assessments take into many forms monitored by national or local boards. However, most of the assessments on academic performance of students adopted the top-down approach using models that fit their needs rather than on the needs of students. Hence, this study is about testing a participatory model to explain and predict academic performance of students.

Most of the studies conducted on the academic performance of students often gave conflicting results not because of the faulty methods used by researchers rather on the complex nature of the topic being pursued. Class attendance, parental involvement in academic activities of students, influence of teacher characteristics, socio-economic and educational background of parents, and family types were included as variables in the attempt to understand and predict students' academic performance [1], [2], [3], [4], [5], [6], [7], [8]. Compounding the problem is the sociocultural context where the study was conducted [3], for sociocultural factors assumed to occupy significant influence on academic performance.

Having assumed that academic achievement is a multivariate phenomenon, previous studies have not incorporated students' perception in the evaluation instrument. Hence, this study deemed it appropriate to incorporate a participatory context in evaluating students' academic performance by incorporating students' views on the different aspects of the evaluative processes. To realize this end, students' perceptions on the factors of their academic performance, known as academic performance indicators, were incorporated into the analysis.

In this study, academic performance of students using their final grades was correlated with the academic performance indicators. In achieving this goal, a three-fold phase was undertaken: a) the establishment of the APIs fitness, b) the classification of the respondents' API index and API, and finally, c) the interpretation of the connection between academic performance indicators and academic performance.

\section{METHODS}

The researchers constructed an instrument called Participatory Educational Assessment Instrument (PEAI). Consisting of three (3) parts, the instrument outlined the academic performance indicators (API) variables, namely: the family support indicators, the instruction support, and the organizational support indicators. 
The formulation of the instrument involved two phases. Phase 1 involved a series of consultations and oral interviews with the students to solicit their perceptions pertaining academic performance. Focus group discussions (FGD) and individual unstructured interviews were the main tool in this phase. After a series of consultations, the factors were listed and reviewed by the FGD participants and oral interviewees.

Phase 2 was the pre-test phase. During the pre-test phase, different sets of students were recruited to answer the instrument, after which the item analysis followed. During the item analysis, some items were rejected for either they had low response rate or were judged to be ambiguous. The remaining items became part of the final instrument arranged according to the response rate.

A total of 202 freshmen and sophomore students coming from a local university, randomly selected, were the respondents of this study. To be included in the study, prospective respondents must have enrolled a general education course in the current school year, 2014-2015.

Respondents in this study belonged to a relatively large family (68\%) with membership of 5-10 with family of procreation the dominant family type (63\%) and family of orientation, the sub-dominant family type $(37 \%)$. The family of orientation has a role in the structure of the Philippine society. As being composed of some close and/or distant relatives, the family of orientation provides support in terms of financial, spiritual, moral, and other material means for the welfare and sustenance of its members. Moreover, the extended family can be a source of provision in times of need such as unemployment, sickness, old age, and bereavement [9].

\section{RESULTS AND DISCUSSION}

\subsection{The Academic Performance Indicators(API): Its Fitness as an Indicator}

The academic performance indicator is comprised of three interrelated variables, namely the instruction-support, the family-support, and the organization-support. These variables were identified by the respondents to have greatly influenced their academic performance as shown in the discussion below.

Instruction-support.This variable is identified by respondents to be directly related to the quality on the delivery of instruction. Teacher competence, the relevance of the subject matter, and instructional policies implemented for the support of instruction including the promotion of the co-curricular and extra-curricular activities were grouped under the instruction-support variable. Fortunately, numerous studies on academic performance were also conducted along this area. For instance, studies on the influence of minimal guidance on students' academic performance, teacher's quality as correlates to academic performance, and the participation of students in both co-curricular and extra-curricular activities, to name a few, pointed out the importance of the quality of instruction in the teaching-learning process [10], [11], [12]. In this particular study, the result-- $\mathrm{X}^{2}(5$, $N=202)=94.95, p<0.001$--corroborated with the findings of the studies mentioned previously, proving the instructional-support is a contributing variable to respondents' the academic performance. According to FGD participants, "teacher competence and availability for teachers for consultation have helped us a lot in our studies", (FGD participants 5 and 6). "Diha'ykausawala'y consultation hours angamo teachers, walako'ykapangutan-an, naglisodko", (In one instance, our teachers do not have consultation hours, I have difficulty in my studies for I have no one to consult with",FGD participant 1). Instruction- support is not only limited to teachers' availability for consultation, but is also extended to teacher competence as well as accessibility instructional materials. "Our teachers are good, but we need more books and other study materials", (FGD 2).

Family-support. Family support variable as defined by respondents is the roleplayed by the family as an educative support to students. Not only limited to moral and financial support, family support variable includes among others but not limited tofamily relationship, integrity of the family, and parental involvement in the educative process. The respondents' perceptions on the role of family in their education is supported by studies undertaken along these themes. The effects of family conflicts on academic performance [13], the influence of family cohesion and its type of union [14] and the role of parental involvement in the educational activities, all prove to influence students' academic performance. These studies and other similar studies conducted along the family's role in the teaching - learning process only establishthat family welfare occupies a primary importance in the design and implementation of any learning activities [15], [16], [9] which are translated into academic performance. If such is the case, then school activities or any part thereof should be undertaken in concurrencewith family participation so that a school - home partnership can be forged to strengthen the delivery of instruction. In this study, the result, $X^{2}(5, N=202)=69.89, p<0.001$ showed that family-support contributes to the academic performance of respondents, affirming the results of previous studies. "Importante man gyudangpamilyasa among studies. Angtanangpaningkamut, para man gudmakatabang mi sa among pamilya", (Our family is a very important factor in our studies. All our efforts are for the good of our family, FGD participant 2,4).

Organization-support. Organization as operationally defined in this paper is an entity regulated by and operating in the school for purposes of enhancing instruction and/or student development. Also known as uniform bodies [17], these organizations are either co-curricularly or extra-curricularly conformed to the objectives and mission of a learning institution. Through these organizations, various opportunities are offered 
to students of which, aside from academic development and leadership skills, other requirements of human capital development are met as well. Furthermore, by joining school organizations, students can develop other skills, e.g. "psychomotor learning, along with emotional, spiritual and mental well-being; $\mathrm{x} \mathrm{xx}$ develop potential talents and interests of students x xx", (p. 344). The result of this study, $X^{2}(5, N=202)=198.04, p<0.001$ conforms to the results of previous studies.

\subsection{The APII and Academic Performance: Its classification}

The APII is the grand mean of the APIs. Having assumed that an APII is a predictor ona respondent's academic performance, it is therefore indicative of student performance. As demonstrated in this study, $93 \%$ of the respondents got an APII between 2.00-1.00 indicating to have a Good - Excellent APII with the remaining $7 \%$ having a Poor - Satisfactory APII.

On the other hand, the final barometer of academic performance is the final grade that students got at the end of the term. Results of this study showed that $85 \%$ of the respondents fell within the broad range of Good - Excellent performance with the $15 \%$ as either having Poor or Satisfactory performance.

Coming from a culture that puts prime importance to education, good grades are indicative of students'academic success. Where competition to land in good paying job is stiff, high academic performance assures survival in the competition. Availability of scholarships and other educational financial grants either academic or non-academic requires impressive grades. Thus, impressive final grades become a requirement for the access of educational opportunities and services.

3.3The Correlation between the APII and the AP

The APIIis the factor onAP as shown in the Pearson correlation result, $r(200)=.215, p=.002$. Improving students' scholastic performance is an objective that challenged educators. This challenge has brought myriads of pedagogical strategies, methods, and educational theories to improve teaching - learning processes as well as strengthen educational programs. Strengthening instructional support in terms of faculty upgrading, provision of teaching materials and making instructional contents relevant, encouraging peer-tutorial pursuits, and upgrading of classroom facilities are vital in the delivery of instructional programs and activities. Furthermore, family support needs a boost aside from its usual role of moral and financial support provider. Finally, the establishment of co-curricular organizations as instructional tool needs intensification to encourage faculty members and students collaborate on activities or projects for the enhancement of educational programs and objectives.

\section{CONCLUSION}

Having established the connection between the academic performance indicators and academic performance of respondents, it can be concluded that the enhancement of the API namely, instruction-support, family-support, and the organizational support, should be the primary focus in every educational program and pedagogical evaluation. Furthermore, it was proven that the inclusion of students' perspectives on the evaluative process on academic performance helped in the understanding of the interplay of the variables contributory to their achievement.

\section{ACKNOWLEDGEMENT}

The authors wish to extend their heartfelt thanks to the students who willingly volunteered to be part of this study. With the numerous hours spent in discussing issues relevant to the research questions, you have extended your expertise.

\section{REFERENCES}

[1] Adenike, A. O. (2013). Effects of family type (monogamy or polygamy) on students' academic achievement in Nigeria. International Journal of Psychology and Counselling, 5(7), 153-156. http://doi.org/10.5897/IJPC10.012

[2] Alokan, F. B., Osakinle, E. O., \& Onijingin, E. O. (2013). the Influence of Parents ' Educational Background and Study Facilities on Academic Performance Among Secondary School Students. Ozean Journal of Social Sciences, 6(2), 27-33.

[3] Chowa, G. A. N., Masa, R. D., \& Tucker, J. (2013). The effects of parental involvement on academic performance of Ghanaian youth: Testing measurement and relationships using structural equation modeling. Children and Youth Services Review, 35(12), 2020-2030. http://doi.org/10.1016/j.childyouth.2013.09.009

[4] Kosgei, A., Mise, J. K., Odera, O., \& Ayugi, M. E. (2013). Influence of Teacher Characteristics On Students 'Academic Achievement Among Secondary Schools. Journal of Education and Practice, 4(3), 76-82.

[5] Muhammad, H., Rafiq, W., Sohail, M. M., \& Saleem, M. (2013). Parental Involvement and Academic Achievement; A Study on Secondary School Students of Lahore, Pakistan. Parental Involvement and Academic Achievement ; A Study on Secondary School Students of Lahore, Pakistan, 3(8), 209-223. 
[6] Okioga, C. K. (2013). The Impact of Students' Socio -economic Background on Academic Performance in Universities , a Case of Students in Kisii University College. American International Journal of Social Science, 2(2), 38-46.

[7] Osonwa, O., \& Adejobi, A. (2013). Economic Status of Parents, a Determinant on Academic Performance of Senior Secondary Schools Students in Ibadan, Nigeria. Journal of Educational ..., 3(January), 115-122. http://doi.org/10.5901/jesr.2013.v3n1p115

[8] Teixeira, A. A. C. (2016). The impact Of Class Absenteeism On Undergraduates' Academic Performance: Evidence From An Elite Economics School In Portugal. Innovations in Education and Teaching International, 53(2), 230-242. http://doi.org/10.1080/14703297.2014.937730

[9] Jaeger, M. M. (2012). The Extended Family and Children's Educational Success. American Sociological Review, 77(6), 903-922. http://doi.org/10.1177/0003122412464040

[10] Akinfe, E. (2012). Teachers' quality as correlates of students academic performance in biology in senior secondary schools of Ondo State, Nigeria. Online Journal of Education Research, 1(6), 108-114. Retrieved from http://m.onlineresearchjournals.org/IJER/pdf/2012/oct/Akinfe et al..pdf

[11] Ekeke, J.-T. H. (2014). Students' Involvement In Extra-Curricular Activities And Their Academic Performance At The Tertiary Level. ATBU Journal of Science, Technology and Education. Retrieved from http://www.atbuftejoste.com/index.php/joste/article/view/37

[12] irschner, P. A., Sweller, J., \& Clark, R. E. (2006). Why Minimal Guidance During Instruction Does Not Work: An Analysis of the Failure of Constructivist, Discovery, Problem-Based, Experiential, and Inquiry-Based Teaching. $\quad$ Educational Psychologist, $41(2), \quad$ 75-86. http://doi.org/10.1207/s15326985ep4102_1

[13] Bahrassa, N. F., Syed, M., Su, J., \& Lee, R. M. (2011). Family conflict and academic performance of first-year Asian American undergraduates. Cultural Diversity and Ethnic Minority Psychology, 17(4), 415-426.

[14] Alika, H. I., \& Edosa, O. S. (2012). Relationship between Broken Homes and Academic Achievement of Secondary School Students in Oredo Local Government Area of Edo State, Nigeria. College Student Journal. Retrieved from http://www.projectinnovation.biz/csj_2006.html

[15] Cheng, W., Ickes, W., \& Verhofstadt, L. (2012). How is family support related to students' GPA scores? A longitudinal study. Higher Education, 64(3), 399-420.

[16] Dumaret, A., \& Stewart, J. (1985). IQ, Scholastic Performance and Behaviour of Sibs Raised in Contrasting Environments. Journal of Child Psychology and Psychiatry and Allied Disciplines, 26(4), 553-580. http://doi.org/doi:10.1111/j.1469-7610.1985.tb01641.x

[17] Bokhari, N., Razali, A., Yusof, F. M., \& Zakaria, N. (2015). Role of Uniform Bodies in Inculcating Leadership Skills. Procedia - Social and Behavioral Sciences, 204, 343-351. http://doi.org/10.1016/j.sbspro.2015.08.164 